\title{
Special needs children: a parent's support in the new normal teaching pedagogy and learning alternative modality
}

\section{Crianças com necessidades especiais: o apoio dos pais na nova pedagogia de ensino normal e na modalidade alternativa de aprendizagem}

\section{Niños con necesidades especiales: el apoyo de los padres en la nueva modalidad alternativa de enseñanza y aprendizaje normal}

\author{
Leovigildo Lito Mallillin ${ }^{1}$
}

${ }^{1}$ Gulf College, Muscat, Omã.

Corresponding author:

Leovigildo Lito Mallillin

E-mail: loviedsunbright_0722@yahoo.com.ph

How to cite: Mallillin, L. L. (2021). Special needs children: a parent's support in the new normal teaching pedagogy and learning alternative modality. Journal of Research and Knowledge Spreading, 2(1), e12739. https://doi.org/10.20952/jrks2112739

\section{ABSTRACT}

The study aims to know the profile of the respondents in terms of age, gender, educational attainment, and monthly family average income of parents and to identify how the support is extended by the parents on their special need children toward their studies along the area of becoming a strong advocate, getting acquainted with school regulation, learning to access additional services, developing relationship with children module tutors, and future of special need children. The descriptive quantitative research design is employed in the study. The subjects of the study are the parents of the special needs children who are enrolled in the different Higher Education Institutions (HEI) both in private and government entities in the GCC country. Twenty (20) parents are topped in the utilization of the study. A non-probability sampling technique is utilized in the study which is purposive sampling because it is appropriate in the development of the study. The results show that there is no significant relationship between the profile of the respondents and how support is extended by the parents of the special need children toward their studies.

Keywords: Acquainted with school regulation. Alternative learning. Learning to access additional services. Parents' support. Special need children.

\section{RESUMO}

O estudo tem como objetivo conhecer o perfil dos respondentes em termos de idade, sexo, escolaridade e renda média familiar mensal dos pais e identificar como o apoio é concedido pelos pais aos seus filhos com necessidades especiais para os estudos na área de. tornar-se um 
forte defensor, familiarizando-se com a regulamentação escolar, aprendendo a acessar serviços adicionais, desenvolvendo relacionamento com tutores de módulos infantis e futuro de crianças com necessidades especiais. O desenho descritivo de pesquisa quantitativa é empregado no estudo. Os sujeitos do estudo são os pais de crianças com necessidades especiais matriculadas em diferentes Instituições de Ensino Superior (IES), tanto em entidades privadas como governamentais no país do CCG. Vinte (20) pais são superados na utilização do estudo. Uma técnica de amostragem não probabilística é utilizada no estudo, que é uma amostragem intencional porque é apropriada no desenvolvimento do estudo. Os resultados mostram que não há relação significativa entre o perfil dos respondentes e a forma como o apoio é dado pelos pais de crianças com necessidades especiais aos estudos.

Palavras-chave: Apoio dos pais. Aprendendo a acessar serviços adicionais. Aprendizagem alternativa. Crianças com necessidades especiais. Familiarizado com o regulamento escolar.

\section{RESUMEN}

El estudio tiene como objetivo conocer el perfil de los encuestados en términos de edad, género, nivel educativo e ingreso familiar promedio mensual de los padres e identificar cómo el apoyo es extendido por los padres a sus hijos con necesidades especiales hacia sus estudios en el área de convertirse en un firme defensor, familiarizarse con la regulación escolar, aprender a acceder a servicios adicionales, desarrollar una relación con los tutores del módulo de niños y el futuro de los niños con necesidades especiales. En el estudio se emplea el diseño de investigación descriptiva cuantitativa. Los sujetos del estudio son los padres de los niños con necesidades especiales que están matriculados en las diferentes Instituciones de Educación Superior (IES) tanto en entidades privadas como gubernamentales del país del CCG. Veinte (20) padres son los mejores en la utilización del estudio. En el estudio se utiliza una técnica de muestreo no probabilístico que es un muestreo intencional porque es apropiado en el desarrollo del estudio. Los resultados muestran que no existe una relación significativa entre el perfil de los encuestados y cómo los padres de los niños con necesidades especiales brindan apoyo a sus estudios.

Palabras clave: Apoyo de los padres. Aprender a acceder a servicios adicionales. Aprendizaje alternativo. Familiarizado con la regulación escolar. Niños con necesidades especiales.

\section{INTRODUCTION}

One of the pressing issues in the educational system at present is the special need children develop toward learning. It is a great challenge and issue to the educational system to be addressed to include the parents' support. Special needs children deserve equal right and equal protection as compared to the normal children (Mallillin, 2017). The principles of the educational needs' apply challenges in the learning problems among children with special needs processes. It outlines and attempts in the aspect of the general system in education for people in helping special needs children toward their learning. It discloses and modernizes the key concept to concise positive educational systems for children with special needs education. It integrates principles and establishes a system in quality education. It changes the global description of the area in special education. It acknowledges the system of special education in accordance to the requirements of the society equitable to quality and access. It provides instruments in the transformation of the system in education principles and competencies in learning. It practices and establishes the structure point and principle substance. It foresees the content of educational adequacy in knowledge and scientific structure of education through attitude, competency, and concrete subject quantity. It identifies expected outcome in 
comprehensiveness standard of education in special need children implementation (Засенко \& Прохоренко, 2018).

On the other hand, becoming an advocate to the special needs children in support of their education provides intensive services in battling to their needs that prevail their skills, tools, and information. It is important to note that children with disability ensure education with appropriate design to provide their needs and equality. Special care given to the exceptional children facilitates better advocacy on their struggles in life and services. It facilitates values and advocacies in their effort to be involved in their school activities and in their assertiveness to their learning process. Parents and teachers are facilitators on resources and knowledge as support to them (Burke et.al, 2019). Hence, inclusion practices of selfadvocacy are developed and designed to guide and to analyze the dimension, knowledge, and their rights. It provides the exceptional students to have their advocate challenges in their learning (Abera \& Negassa, 2019).

In addition, the support given to special needs children from the parents in acquaintance with the school regulation provides provision and guidelines to special curriculum education that enhances the framework in their work of progress into professional educators, individuals, and as parents to strive and to ensure the best practice achievement and process. Special children are peculiar and they have their own need to be safe and stimulating in the care of the environment to be matured and to grow intellectually, emotionally, socially, and physically. It demonstrates the commitment of both parents and teachers to provide and support in the environment safe to develop their potential individual challenges and strengths. It is conditioned in the development of the innovation of parents in the implementation of technologies among them. It ascertains the analysis of their educational learning and experiences (Razumova, Ruslyakova, Bazhenova, Shpakovskaya, \& Tokar, 2019). It also provides the disabilities of learning to a self-regulatory cognitive on the characteristics of the motivation learning influences in support of their special children. It measures the complete disability learning to self-efficacy in their academic performance to intelligence of theory, and goals in the academic preference attribution effort in exerting the context of learning. Special needs children have a disability of learning in their academic low self-efficacy performance of their fixed intelligence due to their late development and have only limited ability in their level. It influences their attribution ability and preferences (Baird et al., 2009).

Consequently, the support given by the parents in the learning to access and additional services is very significant in the learning process of the special needs students' children. It provides support in the development of the child and transition that fits on the right of the special child. It also provides the best plan and support to help in various programs that can enhance their development and learning. It provides and legitimizes effort in the implementation of education inclusion in school. It provides privilege to expand their opportunity to obtain services in the quality of education. It provides balance for readiness in learning adequacy on support and facilities. It gives an indication for children with disability appropriate for their educational services and their needs (Efendi, 2018). Asides, support in terms of concerns, attitudes, beliefs, efficacies, and intention provide services to include the learning processes inside the classroom. It predicts to determine the attempt and intention learning disabilities inside the classroom. This can provide a better positive attitude in the implementation of the learning intention process. It emerges both the efficacy and attitude of the learning inside the classroom (Sharma et al., 2018).

Subsequently, the support given on the development in a positive partnership with the special needs children in school facilitates the student in sharing the significant information to provide better relationships in their studies. It ensures that proper communication is always updated and progress. Communication can be informal or formal through teacher and parents' dialogue. It is known as development on the relationship between the module tutors, parents, and children. This ensures that they are building a work relationship on the support given to 
them. They can share knowledge on the development of the child. They can even show empathy through demonstration and listen actively toward parents' interaction. It describes a development of the protocol of support to the best of their capacity and ability toward learning. It determines and expects on the development in tutoring and helping inclusively at school of learning. It adopts the design and needs analysis in support of them (Santoso \& Rudiyati, 2019, April). However, it establishes and implements the understanding and knowledge on the sustainable development of the child in their education. It explores the education role on sustainability of special need children (Hirst, 2019).

Furthermore, support by parents is important for special needs children because they deserve to be protected and concerned about their future. Parents have many plans about their future so they can live like a normal person. It highlights the development and advances in the promotion of their learning. It is a challenge on their capacity as parents on the survival of their future development and function. It embeds on their system and interaction on timing development which is very crucial in nurturing their children with disability experiences (Masten \& Barnes, 2018). It also stressed consistently that teachers can give support in the determination of the success of their education. The knowledge and attitude of teachers in the success of the special needs children can determine their future development (Kurniawati et al., 2017).

\section{Statement of the problem}

1. What is the profile of the respondents in terms of: age, gender, educational attainment, and monthly family average income? 2 . How support is extended by the parents on the special need children toward their studies along the area of: becoming a strong advocate, getting acquainted with school regulation, learning to access additional services, developing relationship with children module tutors, and future of special needs children? 3. Is there a significant relationship between the profile of the respondents and how support is extended by the parents of the special needs children toward their studies?

\section{Hypothesis}

There is no significant relationship between the profile of the respondents and how support is extended by the parents of the special need children toward their studies.

\section{Theoretical framework}

The study is anchored on the context, culture and disability in a systematic review of historical and cultural theory based studies on the learning and teaching students with special needs or disability, Bal et al. (2020) as this theory deals on behavior and cognitive theories. Teaching students with special needs and disabilities is demonstrated by the cognitive and behavior theories privilege on the analysis of every individual. Cognitive and behavior theories are dominant particularly on special need children. It provides and attempts to teach special needs children for the proposed cognitive approaches on mix physiological to remediate the mobility of physical dysfunction and senses of students with special needs. The student and identification of disabilities and gifted students are highly influenced by every individual and cognitive behavior theories. The intellectual assessment was adopted in the $20^{\text {th }}$ century and may continue for strong hold on identified students on both gifted or children with disability and special needs. Behavior theories and practices have informed the dominant as applied to analysis of the behavior on the common form of teaching special need children. The approaches of learning and teaching fuse an individual bounded point of the learner. The ingrained approach to teaching the special need children or special education design and tends to disseminate and tests the teaching practices and intervention of individual form of special need children that remedy and focus on student deficit and disabilities. It draws increasingly on 
historical and cultural activity theory as a predominant and alternative cognitive and behavioral theories to learning and teaching students with special needs.

\section{Concept of the study}

Figure 1. Dependent and independent variables on special need children and parents' support in the new normal alternative learning.

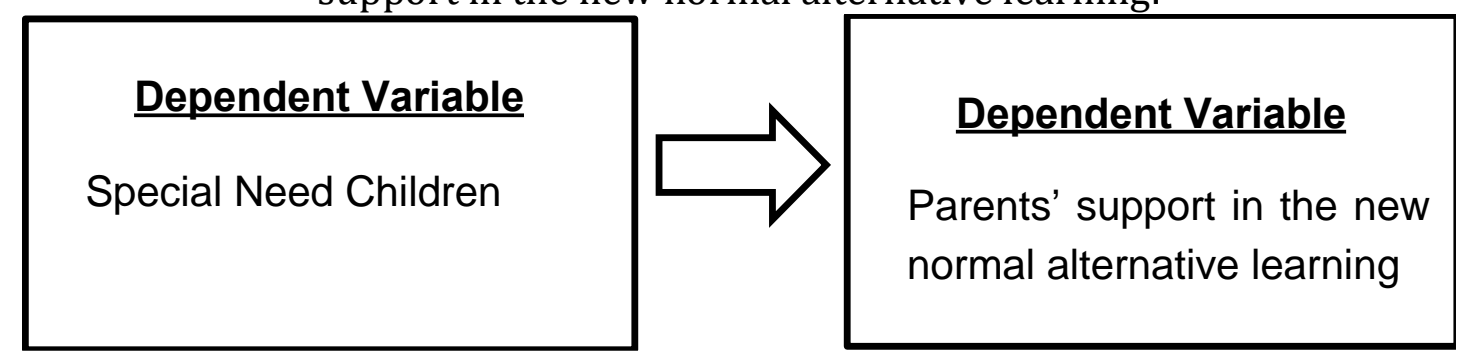

\section{METHODOLOGY}

\section{Research design}

The descriptive quantitative research design is employed in the study because it is an appropriate design on the study under investigation. It provides basic knowledge in the interpretation of applying the findings of the research in support of parents to special needs children. It is a design that provides generated knowledge, shape, and study. It discusses the question purposes and types associated with the special needs children. It reviews the research design to address the question types of the study which interprets the research accordingly, Cook \& Cook (2016).

\section{Respondents of the study}

The subjects of the study are the parents of the special needs children who are enrolled in the different Higher Education Institutions (HEI) both in private and government entities. Twenty (20) parents are topped in the utilization of the study. They are very cooperative because they have special needs children and they want to address and help in the improved educational system and in support of this study.

\section{Sampling Techniques}

A non-probability sampling technique is utilized in the study which is purposive sampling because it is appropriate in the development of the study. It is direct and simple because all the respondents topped in the study have special needs children. This is best in matching the sampling because it provides objectives in the trustworthiness in selecting the samples of the study as to dependability, credibility, conformability and transferability. It outlines the support of the parents to their special need children in terms of becoming a strong advocate, getting acquainted with school regulation, learning to access additional services, development relationship with children and module tutors, and the future of the special need children. It highlights the purposive sampling integration of dependent context design of the study, Campbell, et.al, (2020). 


\section{Research instruments}

Table 1. Support extended as to becoming a strong advocate.

\begin{tabular}{ccl}
\hline Scale & Level & \multicolumn{1}{c}{ Interpretation } \\
\hline $4.20-5.00$ & Strongly agree & Support extended as to strong advocate is highly observed \\
$3.40-4.19$ & Agree & Support extended as to strong advocate is observed \\
$2.60-3.39$ & Neutral & Support extended as to strong advocate is limited \\
$1.80-2.59$ & Disagree & Support extended as to strong advocate is not observed \\
$1.00-1.79$ & Strongly disagree & Support extended as to strong advocate is not observed at all \\
\hline
\end{tabular}

Table 2. Support extended as to get acquainted with school regulations.

\begin{tabular}{ccl}
\hline Scale & Level & \multicolumn{1}{c}{ Interpretation } \\
\hline $4.20-5.00$ & Strongly agree & Support extended as to school regulation is highly observed \\
$3.40-4.19$ & Agree & Support extended as to school regulation is observed \\
$2.60-3.39$ & Neutral & Support extended as to school regulation is limited \\
$1.80-2.59$ & Disagree & Support extended as to school regulation is not observed \\
$1.00-1.79$ & Strongly disagree & Support extended as to school regulation is not observed at all \\
\hline
\end{tabular}

Table 3. Support extended as to learn how to access additional services.

\begin{tabular}{ccl}
\hline Scale & Level & \multicolumn{1}{c}{ Interpretation } \\
\hline $4.20-5.00$ & Strongly agree & Support extended as to access additional service is highly observed \\
$3.40-4.19$ & Agree & Support extended as to access additional service is observed \\
$2.60-3.39$ & Neutral & Support extended as to access additional service is limited \\
$1.80-2.59$ & Disagree & Support extended as to access additional service is not observed \\
$1.00-1.79$ & Strongly disagree & Support extended as to access additional service is not observed at all \\
\hline
\end{tabular}

Table 4. Support extended as to develop a good relationship with special need module tutor.

\begin{tabular}{ccl}
\hline Scale & Level & \\
\hline $4.20-5.00$ & Strongly agree & Support extended by the module tutor is highly observed \\
$3.40-4.19$ & Agree & Support extended by the module tutor is observed \\
$2.60-3.39$ & Neutral & Support extended by the module tutor is limited \\
$1.80-2.59$ & Disagree & Support extended by the module tutor is not observed \\
$1.00-1.79$ & Strongly disagree & Support extended by the module tutor is not observed at all \\
\hline
\end{tabular}

Table 5. Support extended as to future of special needs.

\begin{tabular}{ccl}
\hline Scale & Level & \multicolumn{1}{c}{ Interpretation } \\
\hline $4.20-5.00$ & Strongly agree & Support extended to future special needs is highly observed \\
$3.40-4.19$ & Agree & Support extended to future special needs is observed \\
$2.60-3.39$ & Neutral & Support extended to future special needs is limited \\
$1.80-2.59$ & Disagree & Support extended to future special needs is not observed \\
$1.00-1.79$ & Strongly disagree & Support extended to future special needs is not observed at all \\
\hline
\end{tabular}




\section{RESULTS}

Table 6. Profile of the respondents.

\begin{tabular}{|c|c|c|c|}
\hline Profile & Frequency & Percentage & Ranking \\
\hline \multicolumn{4}{|c|}{ Age } \\
\hline 35 below & 2 & 10 & 3.5 \\
\hline $36-40$ & 2 & 10 & 3.5 \\
\hline $41-45$ & 10 & 50 & 1 \\
\hline $46-50$ & 3 & 15 & 2.5 \\
\hline 51 above & 3 & 15 & 2.5 \\
\hline \multicolumn{4}{|c|}{ Gender } \\
\hline Male & 4 & 20 & 2 \\
\hline Female & 16 & 80 & 1 \\
\hline \multicolumn{4}{|c|}{ Educational attainment } \\
\hline Elementary Level/Graduate & 8 & 40 & 2 \\
\hline Secondary Level/Graduate & 9 & 45 & 1 \\
\hline College Level/Graduate & 2 & 10 & 3 \\
\hline Others: & 1 & 5 & 4 \\
\hline \multicolumn{4}{|c|}{ Monthly income } \\
\hline OMR 10,000.000 below & 1 & 5 & 6 \\
\hline OMR $10,001.000$ - OMR $15,000.000$ & 5 & 25 & 1.5 \\
\hline OMR $15,001.000$ - OMR 20,000.000 & 5 & 25 & 1.5 \\
\hline OMR 20,001.000 - OMR 25,000.000 & 4 & 20 & 3 \\
\hline OMR 25,001.000 - OMR 30,000.000 & 3 & 15 & 4 \\
\hline OMR 30,001.000 and above & 2 & 10 & 5 \\
\hline
\end{tabular}

Table 6 presents the frequency and percentage distribution of the profile of the respondents. It shows that the $41-45$ years age bracket is 10 or $50 \%$ among the respondents. Female respondents' is 16 or $80 \%$ among them. Secondary level/graduate is their educational attainment which is 9 or $45 \%$ among the respondents, and monthly average family income is OMR 10,001.000 - OMR 15,000.000 and OMR 15,001.000-OMR 20,000.000 is 5 or 25\% among the respondents.

Table 7. Support extended as to becoming a strong advocate.

\begin{tabular}{|c|c|c|c|}
\hline Indicators & WM & I & $\mathrm{R}$ \\
\hline 1. Advocate successfully to their rights to learn. & 4.12 & A & 2.5 \\
\hline 2. Advocate successfully to their needs in school. & 4.12 & A & 2.5 \\
\hline 3. Know their rights to communicate effectively. & 4.05 & A & 4 \\
\hline 4. Ask questions about the services being provided for their child. & 3.38 & MA & 5 \\
\hline $\begin{array}{l}\text { 5. Assist their children on their needs in school regarding their growth and } \\
\text { development }\end{array}$ & 4.28 & SA & 1 \\
\hline Average Weighted Mean & 3.99 & A & \\
\hline Standard Deviation & & 0.351 & \\
\hline
\end{tabular}

Table 7 presents the support extended to special need children toward learning along the area of becoming a strong advocate. Assisting their children on their needs in school regarding their growth and development, with $(\mathrm{WM}=4.28)$ or Strongly Agree which means support extended as to strong advocate is highly observed. Advocate successfully to their rights to learn, and Advocate successfully to their needs in school, with (WM=4.12) or Agree which means support extended as to strong advocate is observed. Know their rights to communicate effectively, with (WM=4.05) or Agree which means support extended as to strong advocate is observed. Ask questions about the services being provided for their child, with $(\mathrm{WM}=3.38)$ or Moderately Agree which means support extended as to a strong advocate is limited. The overall $(A W M=3.99)$ or Agree which means support extended as to strong advocate is observed. 
Table 8. Support extended as to get acquainted with school regulations.

\begin{tabular}{|c|c|c|c|}
\hline Indicators & WM & I & $\mathrm{R}$ \\
\hline 1. Support them to maintain the passing mark of their modules. & 4.23 & SA & 1.5 \\
\hline 2. Remind them always of the rules and policies of the school. & 4.23 & SA & 1.5 \\
\hline 3. Teach about the educational rights of children with special needs. & 3.75 & A & 4 \\
\hline $\begin{array}{l}\text { 4. Provide special need families with access to seminars on their special need } \\
\text { children. }\end{array}$ & 3.39 & MA & 5 \\
\hline 5. Navigate or direct special need children to the educational system in the college. & 3.90 & A & 3 \\
\hline Average Weighted Mean & 3.90 & A & \\
\hline Standard Deviation & & 0.354 & \\
\hline
\end{tabular}

Table 8 presents the support extended to special need children toward learning along the area of getting acquainted with school regulations. Support them to maintain the passing mark of their modules, and Remind them always of the rules and policies of the school, with $(\mathrm{WM}=4.23)$ or Strongly Agree which means support extended as to school regulation is highly observed. Navigate or direct special need children to the educational system in the college, with $(W M=3.90)$ or Agree which means support extended as to school regulation is observed. Teach about the educational rights of children with special needs, with $(\mathrm{WM}=3.75)$ or Agree which means support extended as to school regulation is observed. Provide special need families with access to seminars on their special need children, with $(\mathrm{WM}=3.39)$ or Moderately Agree which means support extended as to school regulation is limited.The overall (AWM=3.90) or Agree which means support extended as to school regulation is observed.

Table 9. Support extended as to learn how to access additional services.

\begin{tabular}{lccc}
\multicolumn{1}{c}{ Indicators } & WM & $\mathrm{I}$ & $\mathrm{R}$ \\
\hline $\begin{array}{l}\text { 1. Need to identify the services being provided among their special need } \\
\text { children. }\end{array}$ & 4.20 & $\mathrm{~A}$ & 2 \\
2. Need to know how to use insurance to secure services they need. & 4.00 & $\mathrm{~A}$ & 3.5 \\
3. Need to know how to access mental health services & 4.00 & $\mathrm{~A}$ & 3.5 \\
4. Train to work with children with special needs. & 3.36 & $\mathrm{MA}$ & 5 \\
5. Need to know all the necessary support given to their special need children. & 4.88 & $\mathrm{SA}$ & 1 \\
\hline \multicolumn{1}{c}{ Average Weighted Mean } & 4.09 & $\mathrm{~A}$ & 0.544 \\
\hline Standard Deviation & & 0.54 \\
\hline
\end{tabular}

Table 9 presents the support extended to special need children toward learning along the area of learning how to access additional services. Need to know all the necessary support given to their special need children, with (WM=4.88) or Strongly Agree which means support extended as to access additional service is highly observed. Need to identify the services being provided among their special need children, with $(\mathrm{WM}=4.20)$ or Agree which means support extended as to access additional service is observed. Need to know how to use insurance to secure services they need, and Need to know how to access mental health services, with $(\mathrm{WM}=4.00)$ or Agree which means support extended as to access additional service is observed. Train to work with children with special needs, with (WM=3.36) or Moderately Agree which means support extended as to access additional service is limited. The overall (AWM=4.09) or Agree which means support extended as to access additional service is observed. 
Table 10. Support extended as to develop a good relationship with special need module tutor.

\begin{tabular}{|c|c|c|c|}
\hline Indicators & WM & I & $\mathrm{R}$ \\
\hline 1. Collaborate with special needs teachers to support their child. & 4.20 & A & 2.5 \\
\hline $\begin{array}{l}\text { 2. Inform the special need teacher regarding the behavior of the child in his } \\
\text { learning activities. }\end{array}$ & 3.42 & A & 3.5 \\
\hline 3. Collaborate with special need teacher in managing the behavior of the child & 4.33 & SA & 1 \\
\hline $\begin{array}{l}\text { 4. A thorough communication must be done from time to time regarding the } \\
\text { special needs children. }\end{array}$ & 4.20 & A & 2.5 \\
\hline $\begin{array}{l}\text { 5. Develop a good relationship with both parents and teachers for better learning } \\
\text { development of a special need child. }\end{array}$ & 3.42 & A & 3.5 \\
\hline Average Weighted Mean & 3.91 & A & \\
\hline
\end{tabular}

Table 10 presents the support extended to special needs children toward learning along the area of developing a good relationship with special needs module tutor. Collaborate with a special need teacher in managing the behavior of the child, with $(\mathrm{WM}=4.33)$ or Strongly Agree which means support extended by the module tutor is highly observed. Collaborate with special needs teachers to support their child, and thorough communication must be done from time to time regarding the special needs children, with $(\mathrm{WM}=4.20)$ or Agree which means support extended by the module tutor is observed. Inform the special need teacher regarding the behavior of the child in his learning activities, and Develop a good relationship with both parents and teachers for better learning development of a special need child, with (WM=3.42) or Agree which means support extended by the module tutor is observed. The overall $(A W M=3.91)$ or Agree which means support extended by the module tutor is observed.

Table 11. Support extended as to future of special needs.

\begin{tabular}{|c|c|c|c|}
\hline Indicators & WM & $\mathrm{I}$ & $\mathrm{R}$ \\
\hline $\begin{array}{l}\text { 1. Vigilant about identifying the opportunities of his special needs child in the } \\
\text { future. }\end{array}$ & 4.02 & A & 3.5 \\
\hline 2. Identify the skills of his special child in the future. & 4.02 & A & 3.5 \\
\hline $\begin{array}{l}\text { 3. Help and guide his special needs child in the educational choices base on his } \\
\text { skills. }\end{array}$ & 4.18 & A & 2 \\
\hline 4. Prepare his special needs to be independent for his future. & 4.78 & SA & 1 \\
\hline 5. Help his special need for his social security and benefits in the future. & 3.40 & MA & 5 \\
\hline Average Weighted Mean & 4.08 & $\mathrm{~A}$ & \\
\hline Standard Deviation & & 0.492 & \\
\hline
\end{tabular}

Table 11 presents the support extended to special need children toward learning along the area of future of special need children. Prepare his special need to be independent for his future, with (WM=4.78) or Strongly Agree which means support extended to future special needs is highly observed. Help and guide his special needs child in the educational choices based on his skills, with (WM=4.18) or Agree which means support extended to future special needs is observed. Vigilant about identifying the opportunities of his special need child in the future, and Identify the skills of his special child in the future, with $(\mathrm{WM}=4.02)$ or Agree which means support extended to future special needs is observed. Help his special need for his social security and benefits in the future, with $(\mathrm{WM}=3.40)$ or Moderately Agree which means support extended to future special needs is limited. The overall (AWM=4.08) or Agree which means support extended to future special needs is observed. 
Table 12. Significant relationship between the profile of the respondents and how support is extended by the parents of the special need children toward their studies

\begin{tabular}{|c|c|c|c|}
\hline Variables & $\begin{array}{c}\text { Computed } \\
\text { r value }\end{array}$ & Relationship & Decision \\
\hline \multicolumn{4}{|c|}{ Age } \\
\hline Becoming a strong advocate & 0.011499 & not significant & accepted \\
\hline Getting acquainted with school regulation & 0.011485 & not significant & accepted \\
\hline Learning to access additional services & 0.011515 & not significant & accepted \\
\hline $\begin{array}{l}\text { Developing relationship with children module } \\
\text { tutors }\end{array}$ & 0.011487 & not significant & accepted \\
\hline Future of special need children & 0.011514 & not significant & accepted \\
\hline \multicolumn{4}{|c|}{ Gender } \\
\hline Becoming a strong advocate & 0.007184 & not significant & accepted \\
\hline Getting acquainted with school regulation & 0.007175 & not significant & accepted \\
\hline Learning to access additional services & 0.007194 & not significant & accepted \\
\hline $\begin{array}{l}\text { Developing relationship with children module } \\
\text { tutors }\end{array}$ & 0.007176 & not significant & accepted \\
\hline Future of special need children & 0.007193 & not significant & accepted \\
\hline \multicolumn{4}{|c|}{ Educational attainment } \\
\hline Becoming a strong advocate & 0.012779 & not significant & accepted \\
\hline Getting acquainted with school regulation & 0.012763 & not significant & accepted \\
\hline Learning to access additional services & 0.012797 & not significant & accepted \\
\hline $\begin{array}{l}\text { Developing relationship with children module } \\
\text { tutors }\end{array}$ & 0.012765 & not significant & accepted \\
\hline Future of special need children & 0.012795 & not significant & accepted \\
\hline \multicolumn{4}{|c|}{ Monthly income } \\
\hline Becoming a strong advocate & 0.023028 & not significant & accepted \\
\hline Getting acquainted with school regulation & 0.022999 & not significant & accepted \\
\hline Learning to access additional services & 0.023060 & not significant & accepted \\
\hline $\begin{array}{l}\text { Developing relationship with children module } \\
\text { tutors }\end{array}$ & 0.023002 & not significant & accepted \\
\hline Future of special need children & 0.023057 & not significant & accepted \\
\hline
\end{tabular}

Table 12 presents the significant relationship between the profile of the respondents and how support is extended by the parents of the special need children toward their studies. It shows in the table that when two variables are tested against each other. It reveals that the computed $\mathrm{r}$ value is lower than the critical value of 0.444 , with $\mathrm{df}$ of 18 which is the relationship is not significant and the hypothesis is accepted. Therefore, it is safe to say that there is no significant relationship between the profile of the respondents and how support is extended by the parents of the special need children toward their studies and the alternative hypothesis is rejected.

\section{DISCUSSION}

Parents' support is indeed significant to their special needs children toward their studies. It is effective in different ways that provides positive implication to the family in the community. It provides programs to parents that are useful to address the knowledge and development practice and skills in parenting and modality. It provides challenges and contextual involvement of parents adequate to the physical, emotional, and health issues among their special children (Eddy et al., 2019).

Hence, the profile of the respondents show that they are very willing to support their special needs children because they are at their prime age where support is their main concern. Likewise, to female respondents where they need to provide tender loving care to their special need children, though most of the respondents are secondary level, they stressed the need of helping them on their studies which is important on the development of their children and their 
learning process. They have ways and means in supporting them to sustain their need toward their studies. It is a transformation and traditional responsibilities of parents to mainstream and find themselves as multifaceted dexterous in the responsibilities toward the education of their special need children (Lyn et al., 2020).

Consequently, the extended support to the special needs children toward their learning through becoming a strong advocate to prepare them to exercise their right to learn as compared to the normal children. They have the right to proper education and this is what the parents are pushing for as support to them. They have the right to communicate effectively. Proper services are being provided because they need a tender loving care due to the late development in their aspect of life. Parents do their very best to assist them in their growth, development in life. Parents with disabilities children provide advocates to the special services in their education which is very crucial to the perspective and understanding. It focuses on the support advocates toward social learning and communication. This supports and techniques provide a positive result for them (Burke et al., 2018). In addition, parents play a significant role in their learning process at home and in their environmental education. It influences parents on their advocate and support. It provides recognition to parents on their efforts and challenges. It develops and provides a resilient style of parents' advocacy and persistence to navigate the learning process (Park et al., 2018).

Constantly, the support of parents to their special needs children in getting acquainted with the school regulation can help them to learn and pass in their modules. Support is indeed needed for them since they will remind of the rules and policies to be followed in their studies as part of the process in their learning and development. They teach and have hands-on educational rights. They even support their children to the access of seminars and training to enhance learning among their children with special needs and attention. They even navigate to direct their special need children to the educational system in the college. It helps in the assessment of the educational and pedagogical intervention among them. It is an assessment of inclusive intervention in education that can be addressed to learning diversity and needs (Schwab et al., 2015). Certainly, the attitude and knowledge of parents provides them the courage in sustaining their needs in school because it associated their information and familiarity and support. It provides understanding to the real situation that leads to a positive attitude towards them. It is very important for parents and teachers to know, understand, respond and to manage them well because they have different concerns in their status in life (Narita \& Hamano, 2019).

Conversely, the support of parents to their special needs children on how to access and learn additional services provide to identify the needs of services as support for them like insurance for their security and services need. They need also to know how to access their mental health services and need to be trained to work through with their special condition in life and to know the necessary support among them. It ensures that they learn the essential support and expected additional need of learning. It implies that learning knowledge and needs among them are important (Mitchell \& Sutherland, 2020). Asides, priority must be given emphasis which is allocated as resources for additional support to special need children. It is a collective responsibility to individual learning experiences among them. Parents' access to this information must be given emphasis also as partners to educational learning (Armstrong, 2020). Indeed, parents with special needs and disabilities in life disrupt the development of their children in terms of intellectual, emotional, social, physical, and mental on their career and social life. Likewise, their academic needs are provided necessary services which are special as compared to normal children. It determines the effectiveness of commitment and acceptance to increase their self-esteem (Barida \& Widyastuti, 2019).

Furthermore, development of good relationships with module tutor, parents collaborates with their special needs tutor to support their children on their learning process. They even inform the special needs tutor on the attitude and behaviors of their children with 
disabilities to enhance the learning activities among them. They are very supportive in the collaboration on their module tutor in the management of their special need behavior because learning is a process. There is open and transparent communication from time to time for proper monitoring on their progress. They also develop a good relationship with both parents and teachers for better learning. It is important to note that developmental features of the special needs children as supported by their parents at home and school would mean an increase of their knowledge of learning like the normal children. Support must be given through proper knowledge of education, nutritional knowledge as part of the development, proper care, clean living aspect, and the process. It provides parental guidance on the child aspect of development and needs. It is effective in the proper development of the child with disability. Tutors also need this concept as partners in the education process of the special needs children. The perspective and understanding of the situation requires parenting techniques for proper monitoring and development (Akmal \& Hardono, 2019). Similarly, to programs on parenting intervention behavior and change among special need children. Support is indeed important as part of their tender loving care to their children. This is a very challenging situation on their part. They struggle to care for their special needs children. This includes the dynamic intervention and timing to the child with disability for their support and needs. The intervention determines the support given by the parents along the special needs, issues and conditions. It helps the parent to assess the quality of the improvement of the special need development relevant to its effectiveness and well-being (Bradshaw et al., 2019).

Moreover, parents' support prepares the special need in their future to become independent and mature. They are vigilant in identifying the opportunities that can help them to live a normal life. They also identify their skills and through their skills that is where they can enhance and improve to develop the skills needed. They also guide and help on the choices of their education based on the skills of the special need. They can help them to develop and improve their independence. They are preparing them for their benefits and social security in the future. Yet, opportunities in education prepare them in the future because they are examined on their development and progress aside from their needs. It provides them a better competency in the future (Cooc, 2019). Nonetheless, special need children usually encounter difficulties in their learning process and development due to their situation. Their effort to learn can improve and enhance their adaptability to the achievement of their goal in the environment of learning. The application and the analysis of the trends in the special education support the dimension of their learning process as a device of learning, technique and strategy, learning domain and issue in their environment of learning (Cheng \& Lai, 2019).

\section{CONCLUSION}

It shows that becoming a strong advocate is to assist their children in their needs in school regarding their growth and development.

It shows that getting acquainted with school regulation reveals that there is support given to them to maintain a passing mark in their module and always remind them of the rules and policies of the school.

It shows that there is a need to know all the necessary support given to their special needs children in terms of how to access additional services among the special needs children.

It shows that there is collaboration with special needs teachers in managing the behavior of the special needs child in terms of good relationship with their module tutor development.

It shows that they prepare special needs children to be independent for their future.

Recommendations: (a) parents must know the different services supplied among their special needs children because most of them are asking about what services are being provided for them to become an advocate for them; (b) there is a need to provide a special need family to access seminars and workshops as support for them to have a thorough background in the 
proper handling of special needs children and for them to be acquainted with the rules and regulations in school as well; (c) there is a need to train and to work with special needs children and how to access additional services for them as part of their development and progress in their learning; (d) there is a need to inform the special needs tutor regarding the behavior of the special need children and to develop a good relationship with both parents and module tutors for better learning and progress of the special need child; (e) parents should be vigilant in identifying the opportunities and skills of the special needs children in preparation for their future.

ACKNOWLEDGMENTS: Not applicable.

AUTHOR CONTRIBUTIONS: Mallillin, L. L.: conception and design, acquisition of data, analysis and interpretation of data, drafting the article, and critical review of important intellectual content. The author has read and approved the final version of the manuscript.

CONFLICTS OF INTEREST: The author declares that there are no conflicts of interest.

\section{REFERENCES}

Abera, T., \& Negassa, D. (2019). Self-Advocacy for Inclusion: A Case Study of Blind Students in the University of Gondar, Ethiopia. International Journal of Education and Literacy Studies, 7(2), 1-8.

Akmal, Y., \& Hardono, I. H. (2019). Preparing for Parenthood; Parenting Training Module on six Child Development Aspect in East Jakarta. Jurnal Pendidikan Usia Dini, 13(2), 371-385.

Armstrong, D. (2020). Power and partnership in education: parents, children and special educational needs. Abingdon: Routledge.

Baird, G. L., Scott, W. D., Dearing, E., \& Hamill, S. K. (2009). Cognitive self-regulation in youth with and without learning disabilities: Academic self-efficacy, theories of intelligence, learning vs. performance goal preferences, and effort attributions. Journal of Social and Clinical Psychology, 28(7), 881-908.

Bal, A., Waitoller, F. R., Mawene, D., \& Gorham, A. (2020). Culture, context, and disability: a systematic literature review of cultural-historical activity theory-based studies on the teaching and learning of students with disabilities. Review of Education, Pedagogy, and Cultural Studies.

http://dx.doi.org/10.1080/10714413.2020.1829312

Barida, M., \& Widyastuti, D. A. (2019). Acceptance and Commitment Therapy (ACT) to Improve Educators SelfAcceptance of Children with Special Needs. KONSELI: Jurnal Bimbingan dan Konseling (E-Journal), 6(2), 117-124.

Bradshaw, S., Bem, D., Shaw, K., Taylor, B., Chiswell, C., Salama, M., ... \& Cummins, C. (2019). Improving health, wellbeing and parenting skills in parents of children with special health care needs and medical complexity-a scoping review. BMC pediatrics, 19(1), 301.

Burke, M. M., Meadan-Kaplansky, H., Patton, K. A., Pearson, J. N., Cummings, K. P., \& Lee, C. E. (2018). Advocacy for children with social-communication needs: Perspectives from parents and school professionals. The Journal of Special Education, 51(4), 191-200.

Burke, M. M., Rios, K., Garcia, M., Sandman, L., Lopez, B., \& Magaña, S. (2019). Examining the perspectives of Latino families of children with autism spectrum disorder towards advocacy. Exceptionality, 27(3), 201-214.

Campbell, S., Greenwood, M., Prior, S., Shearer, T., Walkem, K., Young, S., ... \& Walker, K. (2020). Purposive sampling: complex or simple? Research case examples. Journal of Research in Nursing, 1744987120927206.

Cheng, S. C., \& Lai, C. L. (2019). Facilitating learning for students with special needs: a review of technologysupported special education studies. Journal of Computers in Education, 1-23.

Cooc, N. (2019). Teaching students with special needs: International trends in school capacity and the need for teacher professional development. Teaching and Teacher Education, 83, 27-41.

Cook, B. G., \& Cook, L. (2016). Research designs and special education research: Different designs address different questions. Learning Disabilities Research \& Practice, 31(4), 190-198.

Eddy, J. M., Kjellstrand, J. M., Martinez, C. R., Newton, R., Herrera, D., Wheeler, A., \& Lorber, M. F. (2019) Theorybased multimodal parenting intervention for incarcerated parents and their children. In: Eddy, J., \& PoehlmannTynan, J. (Orgs.). Handbook on children with incarcerated parents. Springer, Cham.

https://doi.org/10.1007/978-3-030-16707-3 15 
Efendi, M. (2018). The Implementation of Inclusive Education in Indonesia for Children with Special Needs: Expectation and Reality. Journal of ICSAR, 2(2), 142-147.

Hirst, N. (2019). Education for sustainability within early childhood studies: Collaboration and inquiry through projects with children. Education 3-13, 47(2), 233-246.

Kurniawati, F., De Boer, A. A., Minnaert, A. E. M. G., \& Mangunsong, F. (2017). Evaluating the effect of a teacher training programme on the primary teachers' attitudes, knowledge and teaching strategies regarding special educational needs. Educational Psychology, 37(3), 287-297.

Lyn, J. M. T., Loh, S. C., \& Rosli, N. A. (2020). Mainstream versus Special Needs Educators: Comparisons of Knowledge Levels towards Their Roles and Responsibilities in Supporting Inclusive Education (Guru Arus Perdana berbanding Guru Pendidikan Khas: Perbandingan Tahap Pengetahuan terhadap Peranan dan Tanggungjawab dalam Menyokong Pendidikan Inklusif). Jurnal Pendidikan Malaysia (Malaysian Journal of Education), 45(1), 30-40.

Mallillin, L. L. Crossing the borders: Experiences of teachers in teaching special needs.

Masten, A. S., \& Barnes, A. J. (2018). Resilience in children: Developmental perspectives. Children, 5(7), 98.

Mitchell, D., \& Sutherland, D. (2020). What really works in special and inclusive education: using evidence-based teaching strategies. Abingdon: Routledge.

Narita, Y., \& Hamano, S. I. (2019). Understanding of and misunderstandings regarding epilepsy: a survey of teachers in schools for special needs education in Japan. Epilepsy \& Behavior, 96, 160-164.

Park, S., Foley-Nicpon, M., Choate, A., \& Bolenbaugh, M. (2018). “Nothing Fits Exactly”: Experiences of Asian American Parents of Twice-Exceptional Children. Gifted Child Quarterly, 62(3), 306-319.

Razumova, E., Ruslyakova, E., Bazhenova, N., Shpakovskaya, E., \& Tokar, O. (2019). Innovative technologies of psychological support for children with disabilities. Illköğretim Online, 18(2), 539-548.

Santoso, B., \& Rudiyati, S. (2019, April). Learning model of peer tutor in accompanying special needs children at inclusive school. Proceedings of the International Conference on Special and Inclusive Education (ICSIE 2018), Yogyakarta, Indonesia. Recovered from: https://doi.org/10.2991/icsie-18.2019.46

Schwab, S., Hessels, M. G., Obendrauf, T., Polanig, M. C., \& Wölflingseder, L. (2015). Assessing special educational needs in Austria: Description of labeling practices and their evolution from 1996 to 2013. Journal of Cognitive Education and Psychology, 14(3), 329-342.

Sharma, U., Aiello, P., Pace, E. M., Round, P., \& Subban, P. (2018). In-service teachers' attitudes, concerns, efficacy and intentions to teach in inclusive classrooms: An international comparison of Australian and Italian teachers. European Journal of Special Needs Education, 33(3), 437-446.

Засенко, В. В., \& Прохоренко, Л. I. (2018). Educational development priorities for people with special needs in Ukraine. Education: Modern Discourses, 1, 161-166.

Received: 2 June 2021 | Accepted: 20 July 2021 | Published: 1 August 2021

This is an Open Access article distributed under the terms of the Creative Commons Attribution License, which permits unrestricted use, distribution, and reproduction in any medium, provided the original work is properly cited. 